\title{
RECORD CENTER SEKOLAH VOKASI UGM: ANALISIS KEBUTUHAN, RANCANGAN DAN DESAIN UNTUK TEACHING INDUSTRY
}

\author{
Indah Novita Sari \\ Program Studi Kearsipan, Sekolah Vokasi, Universitas Gadjah Mada \\ indah.novita.s@mail.ugm.ac.id
}

\begin{abstract}
The planning of the facilities to support archival technical activities has become a challenge for archivists in the 21st century. This benefits the efficiency of organizational needs and the overall protection of archives owned by an organization such as Vocational College, Universitas Gadjah Mada. This study is important since every organization needs an inactive records storage, but until now Vocational College has not had it yet. This study aims to determine the needs of Records Center in Vocational College and planning Record Center especially the space and equipment needed.

The method used in this research is literature research method. Data collection techniques used literature study and participant observation. The literature source is used to obtain the data of planning procedure, while participant observation is used to obtain the primary data related to the need and the volume of the archive.

Based on the results of needs analysis, it was found that Vocational College need a Record Center for inactive records storage, student learning facilities and meeting stakeholder needs. The steps to be considered are requirement analysis (calculation of archive volume, space requirement, facility requirement \& infrastructure as well as location selection analysis) space planning and layout. The type of Record Center developed is the Offsite Record Center located in Kulon Progo.
\end{abstract}

Keywords : Records Center, inactive records, Vocational College

\section{Intisari}

Perencanaan sarana prasana menjadi tantangan tersendiri bagi para arsiparis di abad 21. Hal ini memberikan keuntungan bagi efisiensi kebutuhan organisasi dan perlindungan menyeluruh bagi arsip yang dimiliki oleh Sekolah Vokasi, Universitas Gadjah Mada. Kajian ini menjadi penting mengingat setiap organisasi membutuhkan tempat penyimpanan arsip inaktif, namun sampai saat ini Sekolah Vokasi belum memilikinya. Penelitian ini bertujuan untuk mengetahui kebutuhan Record Center di Sekolah Vokasi dan melakukan perencanaan Record Center khususnya ruang dan peralatan yang dibutuhkan.

Metode yang digunakan dalam penelitian ini adalah metode penelitian kepustakaan. Teknik pengumpulan data menggunakan studi pustakan dan observasi partisipan. Sumber pustaka digunakan untuk memperoleh data prosedur perencanaan, sedangkan observasi partisipan digunakan untuk memperoleh data primer terkait kebutuhan dan volume arsip.

Berdasarkan hasil analisis kebutuhan, ditemukan bahwa Sekolah Vokasi memerlukan Record Center untuk tempat penyimpanan arsip inaktif, sarana pembelajaran mahasiswa dan memenuhi kebutuhan stakeholder. Langkah-langkah yang perlu diperhatikan adalah analisis kebutuhan (perhitungan volume arsip, kebutuhan ruang, kebutuhan sarana \& prasarana serta analisis pemilihan lokasi), perencanaan ruang dan layout. Jenis Record Center yang dikembangkan adalah offsite Record Center yang berlokasi di Kulon Progo.

Kata kunci: Record Center, arsip inaktif, Sekolah Vokasi 


\section{PENDAHULUAN}

Banjir informasi, dokumen dan arsip di era Teknologi Informasi menimbulkan tantangan tersendiri bagi para ilmuwan di bidang kearsipan. Kuantitas arsip yang terus bertambah disertai kemunculan arsip media elektronik menimbulkan permasalahan tersendiri dalam hal manajemen dan temu kembali arsip. Sementara di sisi lain, manajemen arsip pada media sebelumnya, masih meninggalkan pekerjaan rumah yang belum usai.

Memasuki abad 20, kita mulai mengenal dan menggunakan komputer. Hal ini berdampak pada hasil aktivitas berupa arsip yang berbentuk elektronik pula. Pada masa sebelumnya, manusia lebih banyak bersinggungan dengan media penyimpanan arsip yang berbentuk kertas. Di Indonesia sendiri, pengelolaan arsip berbentuk kertas bisa dikatakan masih belum optimal. Disisi yang lain, arsiparis dan pengelola informasi mulai menghadapi tantangan dalam pelestarian fisik maupun isi informasi dari arsip yang terekam dalam berbagai media. Penting untuk memastikan dukungan manajemen yang baik beserta sarana dan prasarana yang memadai untuk meminimalisir kemungkinan kerusakan arsip. Arsiparis maupun pengelola dokumen mengenal konsep daur hidup arsip (life cycle) dalam pengelolaan arsip. Secara historis, para ahli mengadopsi ilmu alam untuk menjelaskan siklus arsip terkait penciptaan, penggunaan dan pemeliharaan hingga penyusutan arsip. Proses yang harus dilalui arsip tersebut berlanjut hingga arsip melalui fase dari aktif, semi aktif, inaktif hingga statis. Fokus kajian dalam penelitian ini adalah arsip dinamis inaktif. Arsip dinamis inaktif merupakan arsip yang frekuensinya telah menurun. Frekuensi penggunaan yang telah menurun, seringkali berdampak pada keabaian dalam pengelolaannya. Hal ini dapat dillihat dari lokasi simpan yaitu gudang, loteng maupun tempat serupa yang masih jauh dari standar untuk penyimpanan arsip. Senada dengan yang diungkapkan oleh Mark (2012) bahwa arsip dinamis inaktif biasanya disimpan dalam lemari, ruang bawah tanah, loteng, gudang penyimpanan, unit penyimpanan sewaan atau dimana saja ruang yang tersedia. Lebih lanjut Mark menjelaskan terkait implikasi dari ketidaksesuaian lokasi penyimpanan adalah sebagai berikut:

"Sedikit yang memikirkan akibat
dari tempat penyimpanan tersebut;
basemen banjir, gudang rentan
terhadap kerusakan angin, sarang
tikus di loteng, panas yang dapat
merusak kertas, jamur pada arsip
yang berada dalam kelembaban
tinggi serta bahaya pencurian arsip.
Arsip ditempatkan pada bahaya
potensial, kehilangan dan tidak
sengaja dihancurkan-sehingga
pemerintah harus menanggung
kerugian." (Mark, 2012)

Frekuensi penggunaan yang menurun, sebenarnya tidak mengurangi nilai guna arsip inaktif. Artinya, arsip dinamis inaktif tetap penting untuk dijaga kelestariannya sampai waktu dimusnahkan atau berubah status menjadi arsip statis. Pengelolaan arsip inaktif menurut Patricia C. Franks (2013) menjadi penting karena dapat menghemat biaya tempat penyimpanan arsip aktif yang mahal (filling cabinet), meningkatkan efisiensi pemusnahan arsip, mengurangi kesulitan temu kembali arsip dan menyediakan ruang untuk tempat penyimpanan arsip aktif.

Paparan terkait kepentingan arsip inaktif, memunculkan tantangan bagi arsiparis untuk merencanakan gedung dan sarana prasarana simpan. Arsip inaktif memerlukan tempat penyimpanan khusus untuk penyimpanan atau yang lebih dikenal dengan Record Center. Roper dan Millar (1999) menjelaskan 
bahwa Record Center adalah bangunan atau bagian dari bangunan yang didesain atau disesuaikan untuk penyimpanan murah, pemeliharaan dan komunikasi dari arsip inaktif yang menunggu untuk dimusnahkan.

Para peneliti telah banyak yang mengulas tentang arsip dinamis inaktif dalam beragam perspektif dan landasan teori yang berbeda-beda. Lingkup pembahasan meliputi manajemen arsip dinamis inaktif, analisis proses, gambaran Record Center hingga standar yang harus dipenuhi oleh organisasi. Studi pertama dilakukan oleh Bennedon (1970) yang mengungkap gambaran Record Center dari 6 organisasi yang memiliki ruang simpan dan peralatan yang berbeda-beda sesuai dengan kebutuhan dan kemampuan organisasinya. Studi selanjutnya berfokus pada standar bangunan dan peralatan Record Center. William (1970) mengungkapkan bahwa harus terdapat 6 area yang harus ada dalam Record Center yaitu area penerimaan, pemusnahan, penyimpanan, vault, alih media dan kantor. Studi terakhir yang dilakukan Faber (2010) menyebutkan permasalahan yang timbul dalam manajemen arsip dinamis inaktif adalah pemindahan. Saran dari Faber adalah melakukan persiapan dengan terus berkomunikasi dengan unit pencipta arsip dan waktu yang memadai.

Kajian yang dibahas dalam penelitian sebelumnya merupakan upaya untuk memahami gambaran dan masalah dalam manajemen Record Center, agar kemudian dapat disusun langkah-langkah dalam penyediaan ruang, sarana dan prasarana yang memadai. Terdapat dua isu penting yang harus diperhatikan dalam pembangunan Record Center. Pertama, standar gedung dan penyimpanan arsip inaktif dengan jelas diatur dalam KEPKA ANRI nomor 03 tahun 2000, namun masih terdapat banyak masalah dalam implementasinya. Hasil diskusi penulis dengan mahasiswa prodi kearsipan yang melakukan Praktek
Kerja Lapangan, ditemukan bahwa terdapat instansi yang belum memiliki Record Center, belum layaknya ruangan yang dijadikan Record Center hingga kurangnya ruang untuk penyimpanan arsip inaktif. Kedua, arsiparis mulai perlu melakukan upaya pengembangan Record Center yang sesuai dengan kebutuhan di era digital, namun langkah untuk mengelola arsip-arsip media sebelumnya perlu diperhatikan dengan baik. Hal ini untuk mengurangi resiko kehilangan dan kerusakan arsip bagi generasi yang akan datang.

Hal inilah yang mendorong penulis untuk mengambil fokus perencanaan Record Center di Sekolah Vokasi, Universitas Gadjah Mada. Perencanaan ini merupakan bagian dari proyek pengembangan sistem pendidikan di Sekolah Vokasi dengan model Teaching Industry. Dalam perspektif Teaching Industry, Record Center ini dimaksudkan sebagai sarana pembelajaran praktek mahasiswa hingga perusahaan/ organisasi luar. Sehingga, kajian ini hendak menjelaskan bagaimana perencanaan Record Center di Sekolah Vokasi yang meliputi analisis kebutuhan dan rancangan dan desain untuk Record Center sesuai standar.

\section{TINJAUAN PUSTAKA}

Kajian terkait Record Center sebenarnya bukan hal yang baru dan telah dilakukan oleh banyak ahli kearsipan. Lingkup permasalahan dari penelitian terdahulu juga beragam meliputi manajemen, analisis proses, gambaran Record Center hingga standar yang harus dipenuhi organisasi untuk tempat penyimpanan arsip dinamis inaktif. Namun tidak dapat dipungkiri bahwa kajian terkait Record Center masih belum banyak dikaji sehingga masih banyak permasalahan yang belum dapat terpecahkan.

Studi awal dilakukan oleh Bennedon (1970) dan William (1970) 
yang dijelaskan dalam buku berjudul Reader for Archives and Records Center Buildings. Bennedon (1970) menguji beberapa fitur dari bangunan Record Center baru dengan objek 6 organisasi yang terdiri dari industri dan organisasi pemerintahan. Terdapat 15 faktor yang diobservasi meliputi struktur utama gedung, ukuran, ruangan administrasi, kapasitas, ruang penyimpanan, alat pemindahan, ruang penerimaan arsip, peralatan simpan, pengontrol suhu dan keasaman, alat pencegah kebakaran, tempat penyimpanan microfilm, tempat penyimpanan magnetis, ruang pemusnahan arsip, staf, hingga peralatan komunikasi. Hasil dari kajian menunjukkan bahwa 6 instansi memiliki gedung dan peralatan yang berbedabeda. Bennedon (1970) mengusulkan kepada para manajer yang mendesain Record Center untuk mempertimbangkan ketepatan fasilitas yang digunakan, kontruksi dari bangunan hingga manajemen Record Center. Pada dasarnya Record Center berfungsi untuk menekan biaya penyimpanan arsip dinamis inaktif tanpa mengurangi fungsinya dalam kemudahan temu kembali dan pencegahan hilang atau rusaknya arsip.

Studi selanjutnya dilakukan oleh William (1970) yang menjelaskan terkait standar bangunan dan peralatan pada Record Center organisasi pemerintahan di Amerika Serikat. Indikator keberhasilan Record Center dijelaskan lebih lanjut apabila dapat menyediakan perlindungan untuk record dan memungkinkan penghematan untuk organisasi.

Hasil dari kajian William (1970) menunjukkan bahwa terdapat 6 area yang seharusnya ada di Record Center:

1. Area Penerimaan, dimana arsip dinamis inaktif secara sementara disimpan setelah proses pemindahan.

2. Area pemusnahan, dimana arsip dinamis inaktif dimusnahkan dengan metode tertentu.
3. Area penyimpanan, dimana arsip dinamis inaktif disimpan

4. Vault area yang digunakan untuk menyimpan arsip vital dan arsip statis

5. Area alih media untuk mengalihmediakan arsip pada media kertas ke bentuk microfilm

6. Area kantor, termasuk area perpustakaan, pameran dan konferensi.

Studi yang relatif baru dilakukan oleh Faber (2010) tentang proses pemindahan di Record Center. Faber (2010) mendiskusikan permasalahan yang muncul dalam proses pemindahan yaitu: penentuan tanggung jawab, anggaran hingga tekanan yang muncul dalam proses pemindahan. Hasil dari studi menunjukkan pentingnya komunikasi, penyerahan wewenang hingga hak akses dalam Record Center. Selain itu, harus direncanakan langkahlangkah pemindahan mulai dari 6 bulan sebelumnya untuk menghasilkan manajemen pemindahan arsip dinamis yang baik.

Studi selanjutnya dilakukan oleh Jumiyati (2011) yang membahas tentang Sarana dan Prasarana Kearsipan di Pusat Teknologi Bahan Bakar Nuklir. Fokus kajian dari penelitian adalah sarana dan prasarana untuk arsip dinamis aktif dan inaktif. Hasil dari studi menggambarkan bahwa arsip dinamis inaktif di Pusat Teknologi Bahan Bakar Nuklir belum disimpan pada ruang penyimpanan khusus dengan peralatan yang memadai. Studi yang dilakukan oleh (Jumiyati, 2011) sebenarnya merupakan kondisi tempat penyimpanan arsip dinamis inaktif secara umum di Indonesia. Tidak dapat dipungkiri, masih banyak organisasi pemerintahan maupun swasta yang belum memiliki Record Center untuk penyimpanan arsip dinamis inaktif. Dalam studi terkait Record Center, kebanyakan studi berfokus pada 
gambaran Record Center pada organisasi, manajemen dalam Record Center hingga standar peralatan dan gedung Record Center. Studi ini berbeda dengan studi sebelumnya dengan fokus penulis pada perencanaan Record Center yang melibatkan langkah-langkah analisis kebutuhan yang diperlukan dalam pendirian Record Center. Studi terkait perencanaan Record Center memang belum banyak diulas sebelumnya, terutama jika dikaitkan dengan era digital yang memerlukan perencanaan berbeda dengan masa sebelumnya. Namun demikian, kajian terdahulu akan membawa perubahan untuk perbaikan Record Center di masa yang akan datang.

\section{Perencanaan pembangunan Record Center.}

Tahapan awal yang dilalui dalam kegiatan manajemen adalah perencanaan. Stoner \& Wankel (1993) mengungkapkan bahwa rencana memberikan sasaran bagi organisasi dan menetapkan prosedur terbaik untuk mencapainya. Oleh karena itu, perencanaan Record Center perlu dilakukan dengan baik dan matang sesuai dengan tujuan organisasi. Secara konseptual, Bryson (2006) menjelaskan bahwa strategi perencanaan adalah teknik keberlanjutan dan proaktif yang dapat digunakan sesuai dengan pendekatan sistematis.

Strategi perencanaan Record Center yang digunakan penulis sebagai kerangka analisis adalah kajian dari (Mark, 2012) dan (Patricia C. Franks, 2013). Dalam tulisannya yang berjudul Developing a Records Storage System, Mark (2012) mengungkapkan terdapat beberapa hal yang perlu dianalisis sebelum manajer record mendirikan Record Center. Analisis yang diperlukan adalah analisis kebutuhan, perkiraan biaya, perkiraan volume arsip, perencanaan fasilitas, perencanaan ruang, layout penataan, akses peralatan, software, pemeliharaan hingga proses manajemen dalam Record Center. Namun, penulis akan membatasi lingkup batasan hanya analisis kebutuhan, perkiraan volume arsip, perencanaan fasilitas, perencanaan ruang dan layout penataan.

Analisis kebutuhan dalam perencanaan Record Center dimulai dengan analisis kebutuhan pendirian Record Center atau akan menyewa Record Center komersil. Analisis keuntungan dan kerugian jika mendirikan Record Center sendiri mulai diperhitungkan. Selain itu, perlu diperhitungkan luas bangunan yang dibutuhkan, lokasi bangunan serta kemudahan akses arsip kedepannya. Perhitungan luas yang dibutuhkan dapat diihat pada gambar berikut ini:

Formulas used to estimate volume, capacity, and floor area for space planning

$$
\begin{aligned}
& \frac{\text { Volume of records }}{\text { Stack height } \times 333}=\text { Floor area required } \\
& \frac{\text { Volume of records }}{\text { Floor area } \times 333}=\text { Stack height required }
\end{aligned}
$$

Floor area $\mathrm{x}$ stack height $=$ Volume capacity

\section{Gambar 1. Rumus Menghitung Kebutuhan Luas Lantai}

Sumber: Mary F. Robek, Gerald F. Brown dan David O. Stephens dalam (Patricia C. Franks, 2013)

Perkiraan volume arsip dilakukan dengan menghitung arsip yang dihasilkan oleh organisasi disertai dengan rencana pertumbuhan arsip yang menurut New York State Archives and Records Administration (1994) sebesar tigapuluh persen (30\%). Perencanaan fasilitas dilakukan dengan tahapan penentuan fasilitas yang dibutuhkan, pemilihan fasilitas dan perhitungan fasilitas yang dibutuhkan (seperti rak, boks dan kertas pembungkus).

\section{Standar minimal penyimpanan arsip dinamis inaktif.}

Di Indonesia, telah terdapat standar yang dikeluarkan terkait penyimpanan 
arsip dinamis inaktif yang dikeluarkan oleh Arsip Nasional Republik Indonesia (ANRI). Keputusan Kepala Arsip Nasional Republik Indonesia nomor 03 tahun 2000 telah mengatur standar gedung, ruang dan peralatan untuk penyimpanan arsip dinamis inaktif. Standar tersebut digunakan sebagai pedoman untuk membangun gedung baru atau mengadaptasikan gedung/ruangan yang sudah ada untuk tempat penyimpanan arsip inaktif.

Dalam KEPKA ANRI no. 3 tahun 2000 mencakup bahasan mengenai prinsip, standar gedung, standar ruang penyimpanan serta standar keamanan dan keselamatan arsip. Secara prinsip, tempat penyimpanan arsip dinamis inaktif harus murah, luas, aman dan mudah diakses. Lebih lanjut dijelaskan pula standar gedung dengan pertimbangan yang perlu diperhatikan seperti lokasi, konstruksi dan tata ruang. Standar ruang penyimpanan yang perlu dianalisis yaitu beban muatan, ruang simpan, cahaya, suhu dan kelembaban, rayap, angin, rak dan boks. Hingga standar keamanan dan keselamatan yang mencakup arsip dan lingkungan. Standar minimal penyimpanan arsip inaktif yang dikeluarkan oleh ANRI, digunakan sebagai referensi untuk menganalisis perencanaan Record Center di lingkungan Sekolah Vokasi.

\section{METODE}

Penelitian ini menggunakan metode penelitian kepustakaan. Data dan prosedur perencanaan didapatkan dari sumber pustaka. Hal serupa diungkapkan oleh Zed (2008) bahwa riset pustaka sekaligus memanfaatkan sumber perpustakaan untuk memperoleh data penelitian. Selain itu, penulis juga mengobservasi fenomena, permasalahan, volume arsip dan kebutuhan Sekolah Vokasi akan Record Center. Kerangka analisis yang digunakan untuk mengembangkan Record Center sesuai standar menggunakan KEPKA ANRI no. 3 tahun 2000.

\section{HASIL DAN PEMBAHASAN \\ Analisis kebutuhan}

Perencanaan ini diharapkan dapat mendukung efisiensi dan efektivitas dalam pengelolan arsip inaktif di lingkungan Sekolah Vokasi. Sekolah Vokasi sendiri menghasilkan arsip dalam berbagai media yang perlu diselamatkan untuk berbagai kepentingan. Kepentingan yang dikaitkan dengan aspek hukum, administrasi, keuangan hingga pendidikan.

Record Center menjadi penting bagi Sekolah Vokasi karena beberapa alasan. Pertama, kebutuhan instansi untuk manajemen arsip inaktif yang baik. Hal ini mengingat Sekolah Vokasi memiliki delapan (8) Departemen yang didukung dengan struktur penunjang yang semuanya menghasilkan arsip. Oleh karena itulah, diperlukan tempat penyimpanan yang memang sampai saat ini belum ada di Sekolah Vokasi. Kedua, terdapat Program Studi Kearsipan yang berada di bawah naungan Sekolah Vokasi, sehingga Record Center dapat dijadikan sarana pembelajaran praktek bagi mahasiswa. Saat ini mulai dikembangkan Teaching Industry oleh Sekolah Vokasi yang diharapkan dapat mengakomodir kebutuhan masyarakat dan pembelajaran mahasiswa. Ketiga, jika dikaitkan dengan peluang dalam usaha layanan arsip, kesempatan pengembangan usaha bisnis di bidang kearsipan masih banyak. Sejauh ini, bisnis dalam bidang pengelolaan arsip di Indonesia masih terbatas pada IndoArsip dan Multifiling Mitra Indonesia. Keempat, tantangan di abad 21 adalah fenomena banjir informasi. Oleh karena itulah perencanaan Record Center harus disesuaikan dengan perkembangan jaman dan dapat bermanfaat bagi banyak pihak. 


\begin{tabular}{|l|l|l|}
\hline \multicolumn{1}{|c|}{ Unit Pencipta Arsip } & $\begin{array}{l}\text { Perkiraan jumlah } \\
\text { boks yang } \\
\text { dihasilkan }\end{array}$ & $\begin{array}{l}\text { Total yang } \\
\text { dihasilkan }\end{array}$ \\
\hline $\begin{array}{l}\text { Struktur Organisasi (Pimpinan, Kemaha- } \\
\text { siswaan, Keuangan, PPM, Kerjasama, } \\
\text { Akademik dan SDM) }\end{array}$ & 110 & 770 \\
\hline Departemen di Sekolah Vokasi sejumlah 8 & 50 & 400 \\
\hline $\begin{array}{l}\text { Program Studi di Sekolah Vokasi sejumlah } \\
27\end{array}$ & 20 & 540 \\
\hline Total & 1710 \\
\hline
\end{tabular}

Tabel 1. Perkiraan arsip yang dihasilkan tiap Unit di Sekolah Vokasi

\section{Perkiraan arsip yang dihasilkan oleh Sekolah Vokasi.}

Perhitungan volume arsip merupakan kegiatan yang membutuhkan banyak waktu dan keterlibatan banyak pihak. Oleh karena itu, kajian ini menggunakan sampel volume arsip yaitu pada bagian keuangan, Sekolah Vokasi, UGM. Volume arsip keuangan merupakan hasil praktek mahasiswa angkatan 2015 dalam mata kuliah Manajemen Arsip Inaktif, sedangkan jumlah arsip yang dihasilkan oleh Departemen Bahasa, Seni dan Manajemen Budaya dan Program Studi Kearsipan diperoleh dari jumlah boks yang dititipkan ke roll o'pack milik laboratorium Program Studi Kearsipan. Sampel yang dipilih kemudian dapat digunakan sebagai wakil dari unit pencipta dalam struktur organisasi, departemen dan program studi di Sekolah Vokasi. Jenis arsip yang dihitung di sini adalah arsip konvensional berbasis kertas.

Berdasarkan perhitungan boks yang dihasilkan oleh unit pencipta di Sekolah Vokasi, dapat dihitung volume arsip. Perhitungan volume dapat menggunakan rumus yang dituliskan oleh Santosa (n.d.) sebagai berikut:

$$
\begin{aligned}
\text { Jumlah boks } & =\frac{\text { Volume Arsip } \times 100}{\text { Lebar boks }} \\
1.710 & =\frac{\text { Volume Arsip } \times 100}{20}
\end{aligned}
$$

Volume arsip yang dihasilkan = 342 Meter Linier atau $29 \mathrm{~m}^{3}$

\section{Kebutuhan ruang untuk arsip konvensional.}

Langkah selanjutnya setelah mengetahui volume arsip adalah analisis kebutuhan ruang sebagai tempat penyimpanan arsip. Selain itu, perlu dilakukan perhitungan untuk rencana pertumbuhan arsip. Hal ini untuk mengurangi kurangnya tempat simpan arsip akibat perkembangan organisasi. New York State Archives and Records Administration memperkirakan rencana pertumbuhan arsip sebesar 30\% untuk masing-masing organisasi. Secara lebih rinci, analisis ruang adalah sebagai berikut: (satuan yang digunakan adalah feet atau kaki)

- Volume Arsip dikonversi dalam cu.ft

$$
=1010 \text { cu.ft }
$$

- Pertumbuhan arsip

$$
\begin{aligned}
& =30 \% \text { x } 1010 \text { cu.ft } \\
& =303 \text { cu.ft }
\end{aligned}
$$

- Total volume $=1313 \mathrm{cu} . \mathrm{ft}$

- Rencana kebutuhan ruang (belum termasuk peralatan dan ruang kerja)

Area Lantai yang dibutuhkan =

$$
\text { Volume Arsip }
$$

Tinggi Langit-langit x 0,333

Area Lantai yang dibutuhkan =

$$
1313 \mathrm{cu} . \mathrm{ft}
$$$$
10 \mathrm{ft} \times 0,333
$$ 


$$
=438 \mathrm{sq} . \mathrm{ft}
$$

Ruang kerja untuk 5 orang @ 100 sq.ft = 500 sq.ft

Menurut New York State Archives and Records Administration (1994) idealnya ruang kerja pegawai arsip/arsiparis adalah 100 sq.ft per orang. Dalam tulisan ini, penulis memperkirakan jumlah pegawai pengelola arsip adalah 5 orang.

- Total Kebutuhan ruang (belum termasuk peralatan) $=938$ sq. $\mathrm{ft}$

\section{Analisis kebutuhan sarana dan} prasarana untuk arsip konvensional

Konversi volume arsip dari cu.ft ke $\mathrm{mL}=$ $480 \mathrm{~mL}$

- Boks. Jumlah boks =

Volume Arsip x 100

Lebar boks

(rumus dari Muhidin, Sambas Ali dan

Winata, Hendri, 2016)

Jumlah boks $=$ $\underline{480 \times 100}$

20

Jumlah boks yang dibutuhkan adalah 2400 boks

Jumlah rak statis yang dibutuhkan

- Jumlah rak statis =

Jumlah boks x 1 Meter

Isi Laci x Jumlah Shelf (rumus dari Muhidin, Sambas Ali dan

Winata, Hendri, 2016)

Jumlah rak statis $=$

$\underline{2400 \times 1 \text { Meter }}$

$$
5 \times 5
$$

Jumlah rak statis yang dibutuhkan 96 rak.

\section{Analisis pemilihan lokasi}

Lokasi Record Center merupakan pertimbangan yang perlu diperhatikan oleh manajer arsip. Secara prinsip, arsip inaktif mempersyaratkan penyimpanan yang murah, namun tetap aman bagi kelestarian fisik arsip itu sendiri. Terdapat beberapa pilihan dalam menentukan lokasi penyimpanan arsip. Tabel 2 merupakan analisis pemilihan lokasi Record Center Sekolah Vokasi.

Berdasarkan analisis pada table $2 \mathrm{di}$ bawah, penulis menyarankan untuk mengembangkan offsite Record Center. Secara konseptual, offsite Record Center merujuk pada gedung Record Center yang berada diluar organisasi. Jenis Record Center ini cocok untuk organisasi yang berada di kota besar dimana harga tanah pada lokasi gedung utama cukup mahal. Hasil penelusuran penulis terkait nilai tanah di daerah Yogyakarta dan

\begin{tabular}{|c|c|c|}
\hline Jenis RC & Kemungkinan & Pertimbangan \\
\hline Onsite & $\begin{array}{l}\text { Memanfaatkan ruang di } \\
\text { sekolah vokasi }\end{array}$ & $\begin{array}{l}\text { - Kebutuhan akan ruang kelas se- } \\
\text { makin meningkat seiring dengan } \\
\text { peningkatan jumlah mahasiswa. } \\
\text { - Gedung Vokasi merupakan } \\
\text { bangunan yang sudah tua sehingga } \\
\text { sulit memprediksi kekuatan } \\
\text { bangunan untuk tempat penyim- } \\
\text { panan arsip }\end{array}$ \\
\hline Offsite & $\begin{array}{l}\text { Membangun RC diluar } \\
\text { gedung utama }\end{array}$ & $\begin{array}{l}\text { - Akses arsip jika lokasi cukup jauh } \\
\text { dari gedung utama sekolah vokasi } \\
\text { - Penghematan biaya untuk mem- } \\
\text { bangun record center }\end{array}$ \\
\hline Commercial RC & $\begin{array}{l}\text { Menggunakan jasa pihak } \\
\text { luar }\end{array}$ & $\begin{array}{l}\text { - Kredibilitas dari pihak penyedia } \\
\text { jasa layanan Kearsipan } \\
\text { - Akses arsip jika sewaktu-waktu } \\
\text { dibutuhkan }\end{array}$ \\
\hline
\end{tabular}
sekitarnya pada situs badan pertanahan

Tabel 2. Analisis Pemilihan Lokasi

Diplomatika, Vol. 1, No. 1 September 2017 
nasional (peta.bpn.go.id) sebagai berikut:

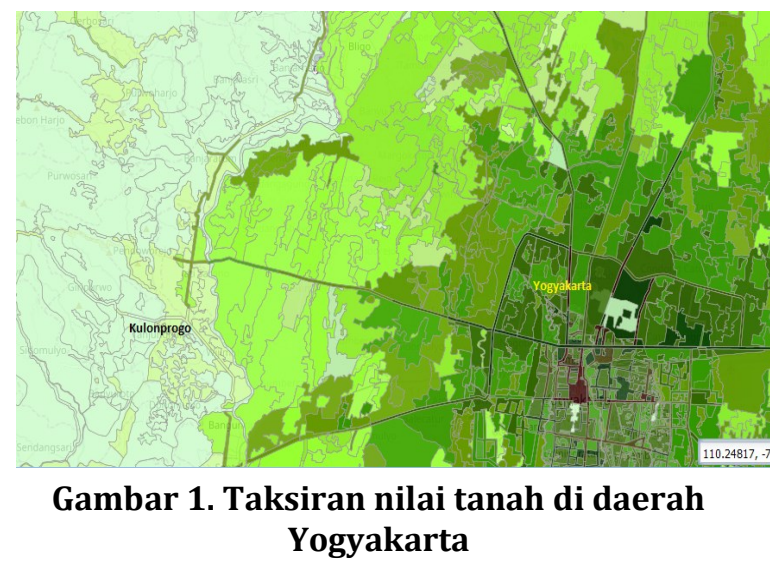

Harga tanah di daerah Yogyakarta mayoritas bewarna hijau tua, yang memiliki nilai diatas 5 juta. Menurut penghitungan, area yang memungkinkan dibangun Record Center adalah daerah Kulon Progo (bagian barat Yogyakarta) dengan beberapa alasan. Pertama, akses dari Yogyakarta ke Kulon Progo terbilang mudah dijangkau (1-1,5 jam). Selain itu, hadirnya teknologi informasi juga dapat memudahkan dalam pengiriman arsip berbentuk elektronik. Kedua, harga tanah di daerah Kulon Progo relatif lebih terjangkau. Ketiga, Sekolah Vokasi mendapatkan hibah tanah dari Bupati Kulon Progo untuk mendirikan fasilitas Teaching Industry yang bekerjasama dengan JICA dari Jepang. Keempat, penggunaan Record Center komersil tidak disarankan karena Sekolah Vokasi memiliki para pembelajar di bidang ilmu kearsipan yang membutuhkan laboratorium praktek.

\section{Perencanaan ruang dan layout penataan.}

Rekomendasi Record Center merupakan bangunan 2 lantai dengan luas 31 x 17 m. Idealnya dalam Record Center terdapat ruang penerimaan, ruang simpan, ruang kerja, ruang administrasi, dan ruang peminjaman (Roper dan Millar, 1999). Namun, penulis mengembangkan perencanaan yang berbeda karena kebutuhan praktek mahasiswa dan arah pengembangan untuk dapat menjadi
Record Center komersil. Berikut merupakan layout dan rancangan dari Record Center Sekolah Vokasi:

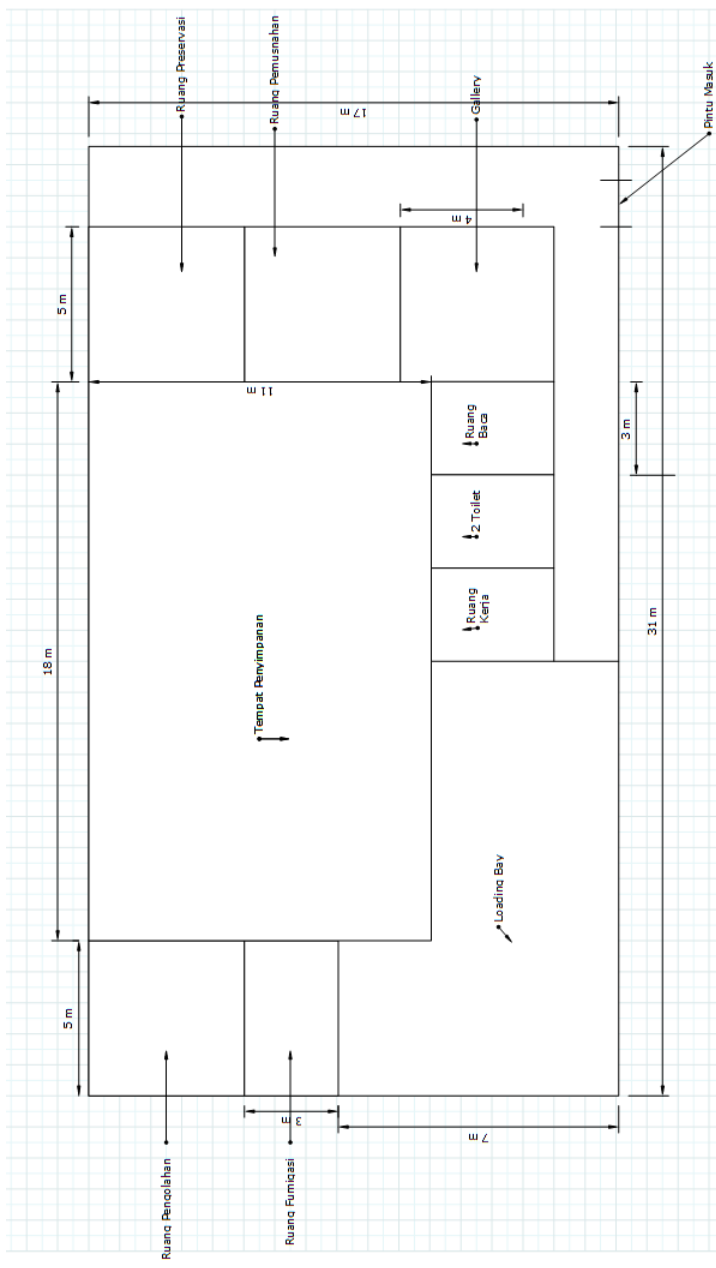

Gambar 2. Layout Record Center Lantai 1

Luas area penyimpanan didasarkan pada kebutuhan ruang penyimpanan (938 sq.ft) dan jumlah rak yang dibutuhkan (96 rak). KEPKA ANRI mengatur jarak antara tembok dan rak sebesar $70-80 \mathrm{~cm}$ serta antar masingmasing rak sebesar 100-110 cm. Selain itu, yang perlu diperhatikan adalah pemisahan antara ruang penyimpanan dan ruang kerja. Penyebabnya adalah perbedaan kebutuhan antara manusia dan arsip dalam hal suhu, pencahayaan dan sirkulasi udara. Pemisahan ruang ini berfungsi untuk menghindari kerusakan arsip dan menjaga kesehatan pegawai arsip. Berikut detail kegunaan ruang beserta alat yang dibutuhkan pada 
rancangan lantai 1 :

\begin{tabular}{|c|c|c|}
\hline Ruang & $\begin{array}{c}\text { Rencana } \\
\text { Peralatan yang dibutuhkan }\end{array}$ & Keterangan \\
\hline Loading Bay & & Ruang penerimaan arsip \\
\hline Ruang Kerja & $\begin{array}{l}\text { Kursi, Meja, AC, Komputer } \\
\text { Filling cabinet }\end{array}$ & $\begin{array}{l}\text { Ruang kerja untuk pegawai } \\
\text { arsip }\end{array}$ \\
\hline Ruang Baca & $\begin{array}{l}\text { Komputer, Meja, AC, Kursi, } \\
\text { Micro reader, Printer, Mesin } \\
\text { fotokopi }\end{array}$ & Tempat peminjaman arsip \\
\hline Gallery & $\begin{array}{l}\text { AC, Alat display, Figura } \\
\text { Lampu }\end{array}$ & Tempat pameran arsip \\
\hline Pengolahan & $\begin{array}{l}\text { Meja besar, Kursi, Boks, Sam- } \\
\text { pul, Kertas deskripsi, Kom- } \\
\text { puter, Printer, AC }\end{array}$ & Ruang untuk mengolah arsip \\
\hline Penyimpanan & Rak, AC, Tangga & $\begin{array}{l}\text { Tempat penyimpanan arsip } \\
\text { yang dapat menampung } 2400 \\
\text { boks }\end{array}$ \\
\hline Preservasi & $\begin{array}{l}\text { Meja, Kursi, AC, Rak lipat, } \\
\text { Hairdrier, Mixer, Blender, } \\
\text { Sprayer, Mesin Press Kertas, } \\
\text { Lampu meja }\end{array}$ & $\begin{array}{l}\text { Tempat melakukan perawatan } \\
\text { arsip }\end{array}$ \\
\hline Pemusnahan & Alat pencincang kertas & Tempat pemusnahan arsip \\
\hline
\end{tabular}

Tabel 3. Fungsi Ruang dan Perencanaan Peralatan Record Center Lantai 1

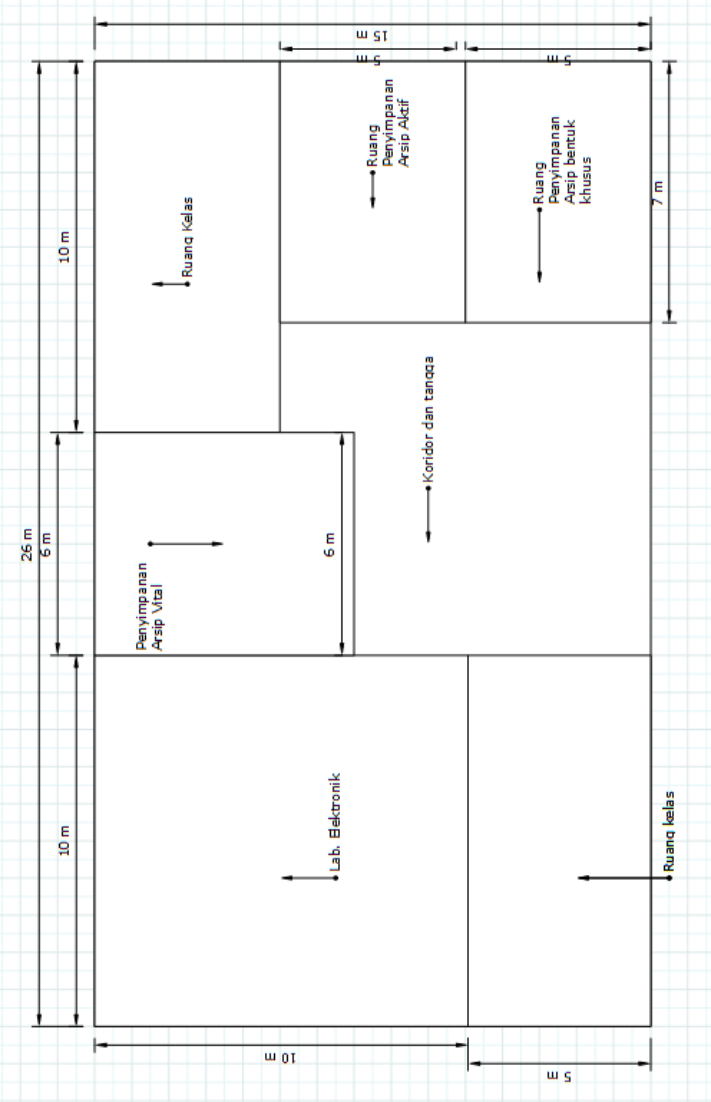

Gambar 3. Layout Record Center Lantai 2 
Perencanaan gedung pada lantai 2 lebih banyak difungsikan sebagai tempat pembelajaran dan penyimpanan arsip yang tidak terlalu padat volumenya. Mahasiswa diasumsikan pulang setelah mengikuti perkuliahan, sehingga mengurangi beban gedung lantai 2. Selain itu, penyimpanan arsip vital diletakkan pada lantai 2 untuk mengurangi resiko kehilangan arsip. Lebih rinci, dijabarkan fungsi dan kebutuhan peralatan untuk gedung Record Center pada lantai 2:
Perencanaan memerlukan dukungan dari pimpinan, unit pencipta dan kemauan dari arsiparis sendiri agar dapat terimplementasi dengan baik. Prosedur perencanaan juga memerlukan tahapan panjang dimulai dari menganalisis kebutuhan dengan menghitung volume arsip, memprediksi kebutuhan ruang, menghitung kebutuhan sarana dan prasarana serta analisis pemilihan lokasi. Selain itu, perencanaan ruang dan layout yang matang akan meningkatkan nilai guna dari Record Center itu sendiri.

\begin{tabular}{|l|l|l|}
\hline \multicolumn{1}{|c|}{ Ruang } & \multicolumn{1}{c|}{$\begin{array}{c}\text { Rencana } \\
\text { Peralatan yang dibutuhkan }\end{array}$} & \multicolumn{1}{c|}{ Keterangan } \\
\hline 2 Ruang Kelas & Meja, kursi, LCD, AC, Papan tulis. & Ruang Perkuliahan \\
\hline Lab. Elektronik & $\begin{array}{l}\text { Set computer, scanner, LCD, AC, } \\
\text { Papan tulis }\end{array}$ & $\begin{array}{l}\text { Tempat alih media dan praktek pen- } \\
\text { golahan arsip elektronik }\end{array}$ \\
\hline $\begin{array}{l}\text { Penyimpanan } \\
\text { Arsip Vital }\end{array}$ & $\begin{array}{l}\text { Brankas, Pengaman ruangan, AC } \\
\text { Pengatur suhu }\end{array}$ & $\begin{array}{l}\text { Tempat penyimpanan arsip vital dan } \\
\text { arsip yang diduga permanen }\end{array}$ \\
\hline $\begin{array}{l}\text { Penyimpanan } \\
\text { Arsip Aktif }\end{array}$ & $\begin{array}{l}\text { Filling cabinet, Map gantung, Index } \\
\text { folder, AC }\end{array}$ & $\begin{array}{l}\text { Tempat penyimpanan arsip yang frekuen- } \\
\text { si penggunaannya tinggi. }\end{array}$ \\
\hline $\begin{array}{l}\text { Penyimpanan } \\
\text { Arsip bentuk khu- } \\
\text { sus }\end{array}$ & AC, Lemari penyimpan & $\begin{array}{l}\text { Tempat penyimpanan arsip ephemera, } \\
\text { peta, gambar arsitektur dan sebagainya }\end{array}$ \\
\hline
\end{tabular}

Tabel 4. Fungsi Ruang dan Peralatan Record Center Lantai 2

\section{KESIMPULAN}

Kelestarian arsip memerlukan perhatian dari pencipta arsip dan arsiparis itu sendiri. Salah satu cara yang dapat dilakukan adalah menyediakan ruang serta sarana dan prasarana yang memadai sebagai tempat simpan arsip. Selama ini, menjadi fenomena yang biasa bahwa arsip inaktif diletakkan di koridor, gudang dan loteng. Sedangkan tuntutan untuk good governance sedang marak digaungkan. Upaya yang dapat dilakukan untuk mengetahui segala aktivitas yang telah dilakukan organisasi adalah menjaga keutuhan fisik dan informasi dari arsip yang dimilikinya.

\section{Perencanaan Record Center} menjadi penting untuk menghadirkan sarana simpan yang layak. Selain itu, perencanaan yang baik dapat mendukung efektifitas dan efisiensi dari organisasi. Penulis mengakui bahwa melakukan perencanaan bukanlah hal yang mudah.
Dari segi praktis, setiap organisasi seperti Sekolah Vokasi yang menghasikan arsip inaktif, diharapkan untuk mulai sadar akan kebutuhan ruang dan sarana simpan. Hal ini untuk meminimalisir resiko dari kerusakan dan kehilangan arsip yang mungkin terjadi di kemudian hari. Kajian ini dapat dijadikan panduan dalam merencanakan Record Center pada organisasi lain. Selanjutnya, penelitian ini dapat dikembangkan dari segi manajemen, kebutuhan SDM hingga kontruksi bangunan Record Center yang baik. Pengembangan dapat dilakukan oleh berbagai disiplin ilmu yang memiliki perhatian khusus pada bidang kearsipan. Harapannya ilmu kearsipan semakin berkembang dan mapan untuk mendukung kebutuhan masyarakat luas. 


\section{DAFTAR PUSTAKA}

Arsip Nasional Republik Indonesia. 2000. Keputusan Kepala Arsip Nasional Republik Indonesia Nomor 03 Tahun 2000 Tentang Standar Minimal Gedung Dan Ruang Penyimpanan Arsip Inaktif.

Badan Pertanahan Nasional. Akses pada www.peta.bpn.go.id tanggal 20 Agustus 2017

Benedon, William. 1970. Features of New Records Center Buildings. US: The Society of American Archivists.

Bryson, J. 2006. Managing Information Services (6nd ed.). England: Ashgate.

Faber, M. J. 2010. "Think outside the box when relocating a records center" in Information Management Journal, 44 (4), 42-46.

Jumiyati, E. 2011. Sarana dan prasarana kearsipan di pusat teknologi bahan bakar nuklir batan, (07), 60-69.

Mark, T. J. 2012. "Developing a Records Storage System" in IIMC Records Management Technical Bulletin Series, 5-7.

Muhidin, S.A., 2016. Manajemen Kearsipan untuk Organisasi Publik, Bisnis, Sosial, Politik dan Kemasyarakatan, Bandung: CV Pustaka Setia.

New York State Archives and Records Administration. 1994. "Developing an Inactive Records Storage Facility" in The State of Education Department, University of the State of New York, (48), 1-20. Retrieved from http://www.archives.nysed.gov/a/ records/mr_pub48.pdf

Patricia C. Franks. 2013. Records \& Information Management. US: American Library Association.

Roper, M. (Ed.). 1999. Managing Records in Record Center. London: International Records Management Trust.

Santosa, H. (n.d.). Manajemen arsip inaktif sebagai solusi permasalahan arsip inaktif tidak teratur. 19-33.
Stoner, J. A. F. 1993. Perencanaan dan Pengambilan Keputusan dalam Manajemen. Jakarta: Rineka Cipta.

Zed, M. 2008. Metode Penelitian Kepustakaan. Jakarta: Yayasan Obor Indonesia. 